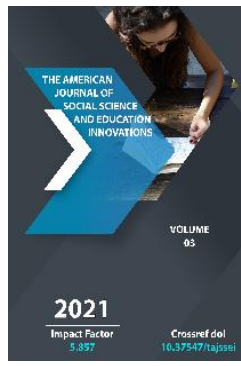

\section{Improving The Content Of Professional Educational Programs On The Basis Of Module-Competent Approach}

Maxsuda Amanova

Republic Of Uzbekistan Ministry Of Higher And Secondary Special Education Pedagogical Innovations, Vocational Education Management And Teaching Staff Retraining And Their Institute Of Advanced Training Methodology Of Professional Education Supply Department Stylist, Uzbekistan
Journal Website: https://theamericanjou rnals.com/index.php/ta jssei

Copyright: Original content from this work may be used under the terms of the creative commons attributes 4.0 licence.

\title{
ABSTRACT
}

Radical reform of the education system, rapid development of science, engineering and technology in the country, as well as consistent changes in the content of education are considered a priority "Improving the functioning of all links of the education system on the basis of modern requirements." modernization of the content of vocational education, teaching technologies and systems for assessing the results of mastering on the basis of a competency-based approach, the creation of didactic support for the formation of competencies is becoming increasingly important.

\section{KEYWORDS}

Professional education, profession, specialization, qualification, training program, educational standard, qualification requirement, curriculum, competence, general competence, professional competence, knowledge, skill object of professional activity, type of professional activity, field of professional activity, academic science, vocational sciences, vocational sciences, general vocational sciences, special sciences, internships, teaching practice, production practice, undergraduate practice, independent study, stationary and portable means of maintenance and repair of machines, mechanisms, devices, agricultural machinery, repair and maintenance. 


\section{INTRODUCTION}

It is noted that today one of the important directions is to improve the quality of training for the labor market in vocational education institutions of developed countries, the formation of their professional competence. In the concept of international education set by UNESCO until 2030, the creation of opportunities for lifelong learning is a global issue, with a special focus on the development of vocational education content based on competency-based modular education programs.

Decree of the President of the Republic of Uzbekistan No. PF-4947 of February 7, 2017 "On the Strategy of Actions for the Further Development of the Republic of Uzbekistan", Decree of the President of the Republic of Uzbekistan PF-5812 of September 6, 2019 It is planned to improve the education system on the basis of advanced foreign experience, to train qualified and competitive personnel for the labor market through the introduction of primary, secondary and secondary special vocational education, and to involve employers in this process.

On this basis, the Decree of the President of the Republic of Uzbekistan "On measures to accelerate the development of agricultural machinery, state support of the agricultural sector with agricultural machinery" dated July 31, 2019 No PP-4410, Ministry of Higher and Secondary Special Education of the Republic of Uzbekistan From the 2020-2021 academic year, in connection with the establishment of training of mid-level specialists based on the needs of the labor market, a list of professions and specialties in need, qualification requirements (professional standards), measures to improve educational programs.

It is planned to introduce a new system of primary, secondary and secondary special vocational education and differentiated educational programs, harmonized with the levels of the International Standard Classification of Education (International Classification).

Consistent measures are being taken in our country to develop the agricultural machinery industry, increase the volume and expand the range of finished products for export, as well as provide the population with locally produced machinery.

At the same time, there is no system of cooperation between domestic agricultural machinery manufacturers, a high share of imported machinery, a lack of a stable system of equipment supply to the agricultural sector, incomplete maintenance of machinery and incompatibility of science and production. requires special attention to this area.

Optimization of existing types of machinery and the introduction of a budget model of new types of agricultural machinery and the creation of a new national "brand" for agricultural machinery produced in the country;

Expansion of production of machinery in horticulture, horticulture and animal husbandry and increase the total volume of production;

Organization of production of small mechanization equipment for agriculture;

Specializes in the optimization of existing equipment and vacant land of machine-tractor fleets, as well as their maintenance and service.

Meets the content of knowledge and requirements for professional competence and the ultimate goals of training in the field of technical and technological specialization of 
agricultural mechanization and service in the Republic of Uzbekistan, as well as the volume of workload and standard requirements of students.

- The main part of the content of vocational education is the implementation of production with theoretical knowledge;

- Didactics and methodology of vocational education in general are based on the labor process, the organization of labor and production;

- In addition to general and pedagogical psychology, the components of the pedagogy of vocational education include occupational physiology and psychology, engineering psychology, technical and economic sciences.

Technical and technological specialists of agricultural mechanization and service perform and organize work on ensuring the operation of agricultural machinery, mechanisms, devices and engineeringtechnological equipment.

Manages the preparation of agricultural machinery and equipment for work, replenishment of assembly units, operation of agricultural machinery, maintenance and repair of agricultural machinery and equipment, repair of individual parts and units, maintenance of machinery and tractors of the agricultural enterprise.

Graduates of technical mechanization of agricultural mechanization and service of professional educational institutions can choose ways to solve various problems arising in the field of professional activity, work in a team to achieve the goals set by the leader, improve their professional skills and personal maturity, work in a focused group, communicate sincerely, politely and effectively with colleagues, managers and customers, express their thoughts fluently in written and spoken language, have universal qualities, love their nation and homeland, be proud of it, national traditions, respect for values, search for information necessary for the effective performance of professional duties, the use of information and communication technologies in their professional activities, work with professional documents will have general competencies.

Disassembly, assembly, disassembly and assembly of agricultural machinery and equipment, adjustment of units, systems and mechanization of engines and electrical equipment, preparation of tillage machines, sowing of seeds, preparation of sowing machines, preparation of harvesting machines, livestock farms, preparation of machinery and equipment for the maintenance of complexes and poultry farms, preparation of working and auxiliary equipment for tractors and machines occupy professional competencies.

Sample curriculum (module) of technical specialization in agricultural mechanization and service for professional educational institutions Model curriculum (module) in accordance with international experience Methodologists of the Institute of Pedagogical Innovations, Vocational Education Management and Retraining and Advanced Training of Teachers, Tashkent State Agrarian University, professors and teachers, specialists of professional educational institutions and employers will be developed and further improved in cooperation with JSC "Uzagrotehsanoatholding", JSC "Uzagroservis".

Curriculum (module) programs of agricultural mechanization and technical service are approved by the Methodological Council of the Institute after discussion at the meetings of the Institute of Pedagogical Innovations, Vocational Education Management and Retraining and Advanced Training of Teachers. The activities of educational and 
methodological associations in the field of special, vocational education are considered by the Coordinating Council and approved by order.

Each curriculum (module) is developed on the basis of qualification requirements of the specialty (qualification) of agricultural mechanization and service, the results of training, knowledge and skills, the name and summary of topics, hours allocated to them, the curriculum (module) and the methods of assessing students' knowledge and skills and the learning outcomes to be achieved at the end.

Curriculum (module) programs of agricultural mechanization and service technicians are clear, structured, allow to make changes in the educational process, assess the results of mastering on the basis of knowledge and skills, knowledge necessary and sufficient for students to master vocational training based on work skills, determines the content and scope of skills, abilities, the sequence of their study.

Reading and drawing of technical drawings, schemes and graphs on the basis of special science (module) programs, drawing sketches of machined parts, description of cuts and sections in them, sizing in drawings, measurement accuracy and assembly requirements (dopusk and posadkas), use of technical literature and reference books, read assembly drawings, schemes. Reading simple and assembly electrical circuits, measuring the basic parameters of simple electrical, magnetic and electronic circuits, working with electrical measuring instruments, starting and stopping electric motors installed on existing machines on the basis of electrical engineering and electronics. Determining the mechanical properties of metals by brand, the use of references in determining the properties of the material, the choice of material for professional activities in construction materials.

Be able to use and formalize standards, determine the limit deviations and deposit values using the table of transfers and transfers of the system of transfers, define the dimensions in the design documentation of constraints and transfers, distinguish between hollow, tension and mixed transfers, graphical representation of transfers and transfers, to mark and read the roughness of the surface roughness in the drawing, to make the right choice of measuring instruments and to lay the foundations of standardization of measurement of details with their help, to perform transitions and technical measurements. Correct selection of recommended lubricants and technical fluids for tractors, combines and agricultural machinery, correct determination of fuel lubricants and maintenance fluids replacement cycles, use of fuel lubricants when working with fuel lubricants and technical fluids. Determines the rational use of tractors, selfpropelled chassis and combines, the ability to disassemble the engine, assembly, adjustment, their preparation for work, detects malfunctions. Plans work on the types of maintenance and repair, access to documentation on maintenance and repair, maintenance and learn to perform repairs independently at the level of technical safety and labor protection requirements, to distinguish between unusable parts using measuring instruments, to use electrical equipment of agricultural machinery to distinguish between unusable parts using measuring instruments.

In order to master the educational program of technical specialization in agricultural mechanization and service, professional educational institutions will be provided with science rooms, laboratory rooms and training rooms and landfills. Practical classes and training internships are organized in 
manufacturing enterprises or other educational institutions, practice rooms and training grounds are organized in employers.

Assessment of the quality of graduates who have mastered the educational program in the field of agricultural mechanization and technical service technology is carried out in the following areas: assessment of the level of mastering the subject (module), assessment of the level of mastering the profession.

\section{CONCLUSION}

- Systematic organization of practical and methodological assistance to vocational education institutions and career guidance among students to continue their future careers;

- Radical improvement of the integration of science, education and industry with the involvement of foreign experts in accordance with international quality standards, the introduction of new scientific and innovative achievements, digital technologies;

- Improving the training of personnel in the field of agriculture on the basis of pilot programs;

- Regularly introduce innovations in educational programs.

\section{REFERENCES}

1. Decree of the President of the Republic of Uzbekistan No. PF-4947 of February 7, 2017 "On the Action Strategy for the further development of the Republic of Uzbekistan",

2. Decree of the President of the Republic of Uzbekistan dated September 6, 2019 PF5812 "On additional measures to further improve the system of vocational education."

3. Resolution of the President of the Republic of Uzbekistan dated July 31, 2019 No PP-
4410 "On measures to accelerate the development of agricultural machinery, state support of the agricultural sector with agricultural machinery". 